\title{
DANCING IN THE HOUSE OF KORYAK CULTURE
}

\author{
Alexander D. King
}

\begin{abstract}
This paper explores two interrelated themes found in the anthropology of ethnic dance ensembles in Kamchatka, Russia: authenticity and the place of individual in society. I use two elite dance troupes (one professional, the other semi-professional) to analyse local categories of cultural authenticity. People in Kamchatka were vocal about representations of indigenous dance on the stage and critiqued dance performances on the basis of whether or not they lived up to their expectations for a proper representation of traditional forms. These critiques are consistently made with respect to the representations themselves and are wholly detached from ethnic (or other) identities of the performers. They provide insight into the nature of authorised knowledge of cultural traditions in Kamchatka. The second part of the paper explores the role of children's dance ensembles in cultural revival movements in small villages. Performing traditional indigenous Kamchatkan dance is not a case of memorising a set stock of moves and positions but entails finding oneself through an individually creative engagement with a style modelled by elders. In both cases, I argue that a semiotics of dance focuses our attention on what symbols do (as opposed to simply what they mean) within a cultural field.
\end{abstract}

Key words: cultural revival movements, culture in Kamchatka, dance ensembles, ethnic dance, semiotics of dance

\section{INTRODUCTION}

Dancing in Kamchatka is an excellent entry point for investigating local ideas about culture and cultural revival. It presents an opportunity for observation, discussion, and interpretation of both unselfconscious activity and self-reflexive ideology. Dances connected to indigenous traditions, in particular, foreground talk about culture and tradition. Many people participate in formal or informal dance ensembles performing indigenous Kamchatkan dance, and nearly everyone has an opinion on these groups, which range from the professional ensemble, Mengo, in the administrative centre, to the village dance group of local children. This essay explores a semiotics of indigenous dance forms and moves toward an understanding of cultural continuity and change and the political economy of ethnic performances. I use Edward Sapir's (1949[1924]) 
provocative terms of 'spurious' and 'genuine' culture to analyse local categories of genuine and spurious ethnic dances and to differentiate good and bad models of culture.

After a short introduction to the main characteristics of dancing in Kamchatka, I set out a theoretical framework for analysing Kamchatkan discourses about indigenous culture and traditions. Much of this discourse centres on the authenticity of two dance ensembles, Mengo and Weyem, and these judgements of authenticity are based on local ideas of how a person acquires authoritative knowledge of traditions. I then analyse dancing and talk about dancing with explicit reference to Peircian semiotics. The subsequent section presents a third dance ensemble, Fakel, which is at the centre of subtle conflicts surrounding the participation of children, in particular, with these traditions. Fakel's founder openly discussed the social power implicit in indigenous traditions, and sees these as a resource for combating anomie among contemporary village youth. I then conclude with some comments on the nature of tradition, culture, and authoritative knowledge in Kamchatka.

\section{DANCING IN THE KORYAK HOUSE OF CULTURE}

All dancing in northern Kamchatka seems to have an ethnicity; disco dancing is European or American, while local dances are identified as Koryak, Even, Chawchu, Chukchi, and so on. Western dance forms are popular among children and youth, but so are dance forms attached to local traditions. Nearly every village has a formal or informal dance ensemble devoted to indigenous dance, usually organised under the aegis of the local klub or dom kul'tury (Russ. 'house of culture'), a school, or through the energies of a particular family. Young people take part in these ethnic dance ensembles for a variety of reasons: fun, a connection to their grandmother, interest in 'our traditions,' enjoyment of the performing arts, and others. The village ensemble in Upper Paren, for example, was organised by the local director of the house of culture for a Magadan Oblast folk festival of some kind, and they performed another time in the nearby town of North Evensk. ${ }^{1}$ They were excited to have an anthropologist in the village, and volunteered to perform for my camera, so delighted were they for an audience. I was told that they also perform at various holidays, but in 1998, it had become more difficult with electricity rationing and the cold, dark premises of the house of culture.

The house of culture is a prosaic institution of civic life in post-Soviet Russia and an intriguing metaphor for Western anthropologists. Bruce Grant used the title In the Soviet House of Culture for his book chronicling the Nivkh 
people of Sakhalin Island and the changing representations of their culture in the twentieth century (Grant 1995). It functions as a civic centre for residents. One can find a house of culture in every city and village (smaller institutions are called a $k l u b$ ) in the former Soviet Union. Ideally, it has a performance space for theatre, dance, and music, as well as practice space and other rooms for everything from children's crafts and folk art to exhibits of the works of local painters and sculptors. In short, a town's house of culture is the place for everything concerning the creative arts.

The house of culture is funded by the government through the department of culture. As in other administrative districts, the Koryak Okrug Department of Culture is responsible for the local art school, a regional museum, the Okrug's House of Culture in Palana, and houses of culture in all of the villages. ${ }^{2}$ Additionally, the Okrug Department of Culture also includes the Okrug's professional dance ensemble, Mengo, which specialises in stage adaptations of native dance. ${ }^{3}$ Thus, although Palana is a small town of only four to five thousand souls, it has a professional dance ensemble, a children's art school, a natural history museum, and a vibrant arts scene centred around the activities of the Okrug House of Culture (okruzhnoi dom kul'tury, often referred to by its initials, ODK), and all are wholly supported by the okrug administration. The content of these cultural activities can be divided into two categories: art (unmarked) and folk/ethnic art. The first category is thought of in terms of modern world culture: oil painting, classical and popular music, modern dance the product of professionals. ${ }^{4}$ The second category references indigenous cultural forms in some way and is usually referred to as fol'klornyi (folk) or natsional'nyi (national or 'ethnic'). Ethnic art includes many activities, but craft production and ethnic dance ensembles are the most salient in public life and generate the greatest amount of discourse on traditions, creativity, and local understandings of 'culture'. Ethnic/folk art is not limited to 'primitives' or indigenes. Russians and Ukrainians certainly have folk dances, and they, too, are performed in Kamchatka. The difference implicit in Kamchatka is that ethnic art is connected to traditions and rooted in a collective past, whereas unmarked art is the contemporary creation of an individual genius.

\section{GENUINE CULTURE VERSUS SPURIOUS CULTURE}

Sapir's article "Culture, genuine and spurious" is primarily a critique of modernity and the soul-destroying meaninglessness of American culture. He uses some standard Boasian tropes of the superiority of supposedly 'primitive' Native American cultures to point out serious social and moral shortcomings in 
contemporary, mainstream American culture, and modernity more generally. I do not think that Sapir would change his argument much if he were alive today. Indeed, consider his example of the meaningful and self-fulfilling activity of spearing fish on the Columbia and Snake Rivers in the American Northwest (Sapir 1949: 316) - now mostly impossible with the building of several dams - contrasted with the physically punishing, mind-numbing, soul-destroying work of cleaning fish for 18 hours a day for four or five months on an oceangoing factory trawler in the North Pacific. Sapir describes spurious cultures as those that reduce people to cogs in a machine. A genuine culture is one that provides everyone with a meaningful place in society:

The self must set itself at a point where it can, if not embrace the whole spiritual life of its group, at least catch enough of its rays to burst into light and flame. Moreover, the self must learn to reconcile its own strivings, its own imperious necessities, with the general spiritual life of the community. It must be content to borrow sustenance from the spiritual consciousness of that community and of its past, not merely that it may obtain the wherewithal to grow at all, but that it may grow where its power, great or little, will be brought to bear on a spiritual life that is of intimate concern to other wills. (Sapir 1949 [1924]: 326)

This Nietzschean understanding of the proper relationship between individual and collective provides me with a platform from which to discuss genuine and spurious models of culture. Spurious models are those which fall into nationalistic traps of essentialising specific traits, or insist on the correspondence of race, language, and culture. ${ }^{5}$ Spurious models of culture consider tradition to be static, definable in terms of a set of practices and beliefs. A genuine model of culture points out the relationships between memory and history in the realisation of traditions, and the fuzzy-edged qualities of cultural margins (I would like to avoid the term boundaries). ${ }^{6}$ Of equal importance, a genuine model of culture avoids the horns of the dilemma of choosing between methodological individualism and the superorganic. The latter term comes from Kroeber (1917), but I refer to all such social theories (e.g., Durkheim, Levi-Strauss) that ignore or erase the place of individual persons in society or history. Methodological individualism is the opposite problem - such a great emphasis on the agency of individuals that the very existence of a society becomes an object of wonder. This problem is sometimes attributed to Bourdieu, though I suspect it is more applicable to less subtle thinkers attempting to follow his lead. A middle ground is necessary for a proper analysis of the interplay between traditions and creativity, terms often opposed to one another in everyday speech. Sapir calls for such a middle ground in his criticism of Kroeber's superorganic (1917), and 
Goldenweiser suggests that such is found in the "biographical individual. He is a historic complex sui generis. Neither biological nor psychological, nor civilisational factors exhaust his content" (Sapir 1917: 449, emphasis original). Nowadays we may be more comfortable with the term person in order to emphasise that our Western Individual is not meant. ${ }^{7}$ Below I discuss relations among persons and collectives in the context of Siberian indigenous traditions of dance.

There are many who snigger at the assorted ethnic dance ensembles performing Siberian dances as inauthentic simulacra of long-repressed, sacred rituals. Authenticity, as typically understood in 'the West' or even as commonly used among anthropologists, is an obsession of museum curators. It is tied to Western ideas of identity and individuals, a singular, unique essence inherent to a performance, event or person and unchanging through time. For example, Benjamin (1968) values the copy made by the cinematographer over the original event of the play or action filmed, but he nevertheless holds the distinction between original and copy to be important. An anthropologically more sophisticated model of culture and performance understands that every instance is both a copy and an original, whether a recording or a 'live' performance. This distinction between original and copy also refers to our obsession with origins, how it 'really happened', and is the key to distinguishing myth from history. Distinguishing the real from the fake or imitation is not necessarily a spurious activity. In this sense, I find judgments of the genuineness of a given performance, artefact, or even personal identity to be very interesting. They remain, however, what Boas called 'secondary explanations', and are more data, not anthropological analysis (1911: 63-69). I believe it is important to remain careful not to impose my cultural categories upon other cultures and different means of differentiation. Good anthropology is properly concerned with the meaningful distinctions operative locally, and not with attempts at sorting a global inventory of traits and artefacts by a universal typology. ${ }^{8}$ I claim that nearly every culture has criteria by which people distinguish real from fake (e.g., real friend, real claims, real wealth, real authority), but the criteria can be different from one culture to another (see Kaneff \& King 2004).

When I asked, "Is this an authentic Koryak dance?" I was only interested in what Koryaks and other local Kamchatkans have to say (King 2004). Although it is interesting, I have not done research on how their European, American, and Asian audiences answer this question (save for those Europeans residing in Kamchatka), and I certainly have set aside my own opinions on this matter. ${ }^{9}$ Likewise, here I do not care what museum curators and other anthropologists have to say on this issue, beyond the value of such statements as expressions of their own cultural categories, that is, as natives (more secondary explanations). I am primarily interested in how native Kamchatkans talk and act. 
Thus, I have been interested in authenticity as a culturally relative category to get at how a particular group of people identify something as being done 'properly' versus 'improperly' or 'wrongly' (cf. Kaneff \& King 2004). ${ }^{10}$ In this essay, I suggest that a semiotics of dance helps us unpack the complex meanings and values attached to dances, cultures, and knowledge.

\section{TALES OF TWO ENSEMBLES}

In the autumn of 1995 I was conducting preliminary fieldwork in Palana, the administrative centre of the Koryak Autonomous Okrug (KAO) in northern Kamchatka. Through contacts in the local teacher's college and the regional museum, I became acquainted with Valeri and Liza Yetneut and their dance ensemble, Weyem, many of whom were students in the teacher's college. Yetneuts had previously danced with Mengo, the KAO's first and only wholly professional dance group of any kind. Mengo started as an amateur group of young, artistically minded indigenous elites working in the administration or in the Okrug's House of Culture, but became a professional group in 1974, when the young ballet master Alexander Gil arrived from Ukraine to take up the post as managing and creative director. ${ }^{11}$ Gil settled down in Kamchatka and married a native woman. He was murdered in 1986 while on holiday in Ukraine, but by then had already established his place as a giant figure in the Kamchatkan arts scene. Valeri Yetneut worked with Gil in Mengo for some time before leaving the group to pursue his own creative ambitions. Yetneut spent two years working with Ergyron in Anadyr, the official dance ensemble of the Chukchi Autonomous Okrug, before returning to Kamchatka and founding Weyem in Palana. By the end of 1995 Weyem had achieved considerable fame locally, and Yetneut was also noted for his other artistic talents, including guitar playing, song composition, and even Tuvan throat singing. I talked to him about his work and its connections to Koryak culture and ethnic identity. My wife and I attended several Weyem rehearsals and began a friendship with Yetneut and his family. On the eve of our departure, we attended a special event marking the fifth anniversary of the teacher's college, where both Weyem and Mengo performed to a packed house of wildly enthusiastic children and adults. This was my first introduction to the importance of local house of culture activities both for performers and audiences.

My main period of research in 1997-1998 was marked by the tragic death of Valeri Yetneut in September 1997 under suspicious circumstances. ${ }^{12}$ Although I cannot make claims to having been Valeri's friend, my wife and I were in the process of becoming friends with Valeri and his wife Liza, and Valeri's unex- 
pected death deeply affected me. This personal shock was compounded professionally, as I had planned to use Yetneut and Weyem extensively in my dissertation. Valeri's death was much more than the loss of potential data, but I was able to widen my investigations to include observations and discussions with many artists in Palana, including people working with Mengo. Weyem has continued to perform under the leadership of Vasili Baranikov.

During this time, Mengo also saw a change in leadership, although not as dramatic. Mark Niuman, a friend of Gil, long-time Kamchatkan resident, also married to a native woman active in Mengo and other dance ensembles, became managing and creative director of Mengo in the autumn of 1997. ${ }^{13}$ Niuman's first project was a special performance commemorating Gil's posthumous 55th birthday - for which he and other Mengo 'old timers' choreographed Mengo's core repertoire as Gil had originally staged it in the 1970s and 1980s. This provided me with an excellent picture of what those dances looked like, as well as a current topic of conversation and gossip. A common complaint against Mengo at that time was that it was 'old and stale'; Gil was brilliant, but the ensemble had not moved on after his death in the ensuing decade. One has to wonder if Weyem as a group will end up making similar gestures to its founder, and if it will become subject to the same criticisms of staleness that people levelled at Mengo. My investigation of local discourses and practices of dance connected to these two elite groups was balanced by research in smaller, demographically native villages in the various regions of the okrug, where I focused on the image of Koryak (and other indigenous) culture in schools, everyday conversations and practices, and the many dance ensembles organised by village houses of culture or energetic individuals. ${ }^{14}$

'Doing it right' was a central preoccupation of nearly everyone, and performances were often critiqued in terms of their accuracy or lack of authenticity in replicating indigenous traditional dance forms. Many of these conversations occurred while watching videotapes of performances at special festivals. These festivals ranged from local holiday celebrations of one kind or another in a village, to district and regional competitions and special events hosted in the okrug centre of Palana or the main city of Petropavlovsk-Kamchatskii, far to the south. The most important events were in Moscow, and groups occasionally travelled abroad for international folk events or on exchange programs linking indigenous peoples of the North (particularly with Alaska, Canada, and Scandinavia). Many Kamchatkan ensembles, including Mengo and Weyem, performed in Moscow as part of a combined celebration of the city's 850th anniversary and the 300th anniversary of the unification/conquest of Kamchatka with/by Russia in September 1997. About a month later, a group of people involved in the Okrug Department of Culture watched a videotape of the Mos- 
cow festival one Friday evening in my living room. An Even ensemble from central Kamchatka began their routine, and one of my guests launched into a heated critique, pointing out all the Koryak movements in what was supposedly an Even dance. She stressed that their postures were "wrong" and the leaps were "Koryakised". This lead her to comment on the culturally inaccurate performances of Mengo. "Their dances look a lot like Mengo performances," she complained. When Weyem took to the stage and began dancing, my friend said that she loves their Even dance:

They dance just like our grandmothers in Ayanka, don't they, Volodya? [addressing a young man sitting near her]. I love Weyem because every time I see their Even dance, I am reminded of our grandmothers. They have all the moves, get down really low. Those grandmothers can get down really low and dance.

This remark highlights the importance of the elders and perceptions of how elders dance in judging the meaning and value of a given performance. Dance ensembles that present (or are at least taken as presenting) their performances as icons of tradition are judged precisely on this basis - the degree to which the ensemble's performances resembles that of the elders, the embodiment of traditional knowledge and action. Yetneut also criticised Mengo for poor iconicity (getting it wrong). His solution to the problem was not to turn to his own intuitions, or to rely only on the vast knowledge of his elderly mother, widely respected for her knowledge of Koryak and Chukchi traditions. Instead, he got a video camera and did fieldwork, taping elders at fishing camps and at the reindeer herds. ${ }^{15}$ His claims to authentic representations were often validated, but even those who critiqued Yetneut did so in the same terms - do his dances resemble those done by elders, or did he "just make them up"? Most people associated with Mengo dismissed accusations of inauthenticity as artistically irrelevant criticisms. They insisted that, although Koryak traditions may have inspired some pieces, they were not performing traditional ethnic dances, but contemporary art. However, those who praised Gil and the authenticity of his choreography of native dance, did so in the same terms used for praising Yetneut's and Weyem's authenticity: Gil had visited elders at the fishing camps and observed the way the elders walked, moved, and danced, and replicated those forms on the stage. He learned specific traditions from the authorised bearers of that knowledge - the elders. 


\section{A SEMIOTICS OF CULTURE AND DANCE}

Dance in Kamchatka is pregnant with meaning, polysemic and ambiguous in some ways, yet clear in significance in others. The meaning created through dance is a function of its qualities as a sign. Following C. S. Peirce (1998: 4-22, 267-300), I understand the significance of a sign resulting from its tripartite relationship with its object (that which is referred to) and with its interpretant (the concept generated in a mind). This triad of meaning contrasts with Saussure's dualistic equation of sign = signified + signifier. Peirceian semiotics does not admit dualities, and the sign is not equivalent to object plus interpretant, but is related equally with each, as are the three points of an equilateral triangle.

Peirce's typology of signs is complex, but here I want to focus on the best known and most easily grasped categories of icon, index, and symbol. Insofar as a choreographed dance resembles an elder's dance, it is an icon of tradition; the meaning of the dance-sign is based on its resemblance to its object (traditional dance). Other meanings of a dance are indexical; they have a direct, real connection with elders themselves, evidence of a relationship between dancer and her mother, her grandmother, or other elder who cultivated those forms in the dancer. Performing a dance is also an index of knowledge (or its lack) of a specific culture. The symbolic aspects of dance are analogous to language. Just as the Koryak word titkatit is an arbitrary symbol for the object English symbolises with the word 'sun', the specific body postures that are identified as 'Koryak' or 'Even', etc., are arbitrary. There is no necessary connection, but the symbol nevertheless presents itself as so; if one is doing an Even dance, then the moves must be Even, and not Koryak, just as one should use English words when speaking English and not Koryak words. I do not discuss the qualities of the dance moves as symbols, the forms and extended meanings of postures and sequences, for that would involve a long and complicated detour into ethnochoreography. Here I want to focus on the meanings of dances through their simultaneous iconic and indexical properties.

A virtue of Peirceian semiotics over Saussure or other theories of the sign is its triadic understanding of meaning. The interpretant is integral to the production of meaning for Peirce, keeping people firmly in view in any discussion of meaning and value, which necessarily change as the interpretant (a mind) changes. Semiotic analyses of reality are intrinsically connected to understanding multiple points of view and lend themselves to the intersubjective objectivity of current anthropological concerns. A second key difference between Peirceian and Saussurian theories of the sign is that language is not 
accorded primacy of place in Peirce's science of signs. While Saussure (1959) holds language to be the prototypical sign system by which all other kinds of sign systems may be understood, Peirce demonstrates that language is but one system among many possible ones. Finally, semiotics is not limited to unpacking the meaning of signs; it is concerned not so much with what signs are saying (contra Geertz) as what they are doing (see Silverstein 2004, 2005).

Iconicity is more than mimesis, which necessarily implies alterity (Taussig 1993). Icons are not copies of originals; they are signs that resemble their referents. This is more than a shift in jargon. Taussig focuses on the mimetic as copying, and originals are implicated in any copy. Referents are not originals but antecedents in the same way that elders are not the originators of tradition, but the current carriers of traditions. Among people in Kamchatka, particularly among indigenous people, traditions are what the elders do and know, not a disembodied set of knowledge codified in texts (sacred or folkloric) and supposedly belonging to a lost golden age. ${ }^{16}$ Since the elders are the embodiment of tradition, change is built into this folk-model of culture and tradition. Dances as icons are simultaneously indices of the relationship between juniors and elders. They point to a person's relationship with specific elders, whether that be one of researcher-subject, as in the case of Yetneut, or one of grandparent-grandchild, as in the case of many family ensembles based in smaller villages.

Dance in Kamchatka is a good synecdoche for culture in Kamchatka because it is available to anyone. There are no secret or esoteric dances, just as religious knowledge, oral traditions, hunting techniques, sewing, or any other body of knowledge or technique that may be construed as particularly 'Koryak' (or Chukchi or Itelmen or Aliutor, etc.) are all open to those who are curious to learn about them, natives or outsiders. Dances are embodied, ephemeral performances and are also the subject of much discussion and evaluation. They include conscious elements of movement and rhythm, as well as unconscious processes of embodiment, ideas of the person, and power. They are caught up in discourse about 'traditions' - Koryak dances must resemble something attributed to antecedents - and yet are the epitome of the creative arts. Individuals are famous for their particular style of dancing, dancing which is both 'Koryak' (and thus makes sense as part of a tradition) and individual (identifiable as 'his' dance or 'her' particular style of movement). Thus, understanding tradition and creativity in Kamchatka requires that we not lose sight of Goldenweiser's biographical person. 


\section{THE POWER OF DANCE}

Cultural revival is at the forefront of Kamchatkan discourse on indigenous groups. Public forums are dominated by groups such as RAIPON (Russian Association of Indigenous Peoples of the North) and local officials and activists. Small dance ensembles play a significant part at the "grass roots", and they are sometimes supported by official channels through subsidies for transport to perform at festivals of one kind or another. These rare opportunities to travel outside the village provide youth with real incentives to participate. Many of these groups are led by junior elders - middle-aged men and women who may have one or two grandchildren already, but also have younger children of their own and still look to senior elders for guidance in defining tradition. While dance ensembles and other practices of explicit cultural revival may superficially seem like recreation, they are part of a life and death struggle in rural Siberia. Yetneut's death was remarkable in his community, but not unique or even rare. Young people all across Siberia are dying in unprecedented numbers due to violence of one form or another, often in connection with alcohol abuse (Pika 1999). Many junior elders see this violence as a symptom of a moral crisis paralleling the economic and social crises of post-Soviet Siberia. ${ }^{17}$

One such junior elder is Nina Nikolaevna Milgichil, who worked as a teacher in the music school in Manily when I talked to her in 1998 and again in 2001. She has formal training in choreography and teaching dance and a folkloric curiosity. She founded and for many years directed the dance ensemble Fakel ('Torch' in Russian, for one of their dances with torches). She has also made a point of documenting knowledge of the elders in her own papers and notebooks, occasionally sending information to the folklore centre in Palana for publication. Milgichil has also read every book she could on the subject of Koryak culture and traditions. Milgichil is a critical reader, and does not hesitate to disagree with ethnographers or other authorities when the printed version deviates from what the elders have taught her. I gave her a copy of the recent translation of part two of Jochelson's ethnography of the Koryak (1908). She found much interesting material in Jochelson (1997) and it fitted well with her understanding of Koryak traditions learned from elders in the mid-to-late twentieth century. She has learned a lot from the "grandmothers" (her word), especially her mother's sister, who was widely respected for her knowledge and power. Milgichil is also a synthetic thinker, looking for how details fit into wider patterns of culture. As she explained to me in 1998:

Stories are just parts of the system. One story gives you this bit [gestures with left hand], another over here [gesturing with right], but it's hard to get the whole system [of religion]. 
She was interested in Jochelson's discussion of Koryak religion because the only book she had addressing the subject suffered from an enduring Soviet ideology and got many of the facts wrong (Krushanov 1993).

We talked often of religion; it had become a contentious topic for her in the 1990s. Protestant missionaries had come from the main city of PetropavlovskKamchatskii with a guitar and books. They organised meetings and targeted young people with evenings of songs and sweet snacks. They talk about God, but some people seemed to have gotten strange messages. For example, one man claimed that he learned that he was not allowed to work. Another refused to repay a debt with the phrase, "God forgives". Although many of these missionary organisations are associated with churches based in the United States, they have an established institutional structure in Kamchatka. As in Manily, there are active Protestant churches in Lesnaya, Tymlat, and Palana, and in all of these places, young native people seem to be the primary (although certainly not exclusive) target of missionary activities. Cynics told me that young people are willing to join any group that will feed them. In one conversation on Koryak religion, myth and ritual, Milgichil explained to me that she understood that children want a morality, and they were not getting any at home. Their parents are the generation raised in the Internat, or boarding school. They were not raised and taught by parents, so they do not know how to raise and teach their own children. In a nearly anthropological vein, Milgichil explained to me how ritual is an important part of religion, morality, and selfknowledge or self-respect. Although elders have stopped observing Koryak rituals, if someone does host one, many people are interested and they attend. Conflict arises from the total prohibition on anything associated with indigenous tradition by the Protestants, who inveigh against speaking traditional languages and wearing fur clothes, as well as performing the old rituals or even performing in ethnic dance groups. Thus, these missionary groups create sometimes bitter divisions among family and friends in villages which can be as small as 1,000 people.

Drumming and dancing in Kamchatka is linked in one way or another to the spirits. Nearly all indigenous dance is accompanied by a skin frame drum, and drums have at least latent spiritual connections. The dance ensemble and public performances may have been ethnic spectacles denuded of spiritual power from the Soviets' point of view, but Nina Milgichil is using them in her own efforts of cultural revival and her private battles against missionaries and social anomie. Sounding Durkheimian, Milgichil told me how two different girls had hanged themselves in the previous couple of years:

Young people see no way out, and their souls are empty. No one passed them anything. They don't know anything. When they see grandmoth- 
ers doing something, anything, any kind of ritual (usually in secret), they call it shamanism. It's not, but they call it that because they don't know any better.

The complaint that "youth are no good anymore" is a common one. However, Milgichil is uncharacteristic in putting responsibility on this state of affairs squarely on the shoulders of the elders. Parents and elders must take responsibility for their youth, and if young persons have empty souls, it is not their primary fault. Equally atypically for post-Soviet Siberia, Milgichil does not wish that someone else would take charge, that the state or "they" would help out and fix things. She is doing what she can with her own time and resources to imbue youth with a sense of the sacred that provides them with moral grounding and a sense of self-respect. In very subtle ways, she proselytises her own, indigenous religion in a quiet religious battle over the souls of young people in her village. In our conversations about dance, ritual, and religion, Milgichil often rejected the label 'shamanism' for her beliefs and practices, and preferred to call it 'Koryak religion'.

Most native Kamchatkans I have encountered dislike the terms 'shaman' and 'shamanism' (cognates in Russian), or, at least, are uncomfortable talking about their traditions in those terms. Obviously some of this discomfort is connected to murderous Soviet repressions of individuals labelled as shamans and general policies discouraging any sacred practices. New Christian missionaries have picked up where the Soviets left off, at least in ideological terms, and they label nearly all indigenous traditions as 'shamanism'. The 'sects' (sekty in Russian) prohibit their members from anything remotely smacking of shamanism, including dancing, singing, or playing a Koryak skin drum. This way, Fakel had lost some of its most promising dancers. In 2001, Protestant missionaries had converted several teenagers once active in Fakel, and Nina Nikolaevna was concerned about the children of the village who had left her dance group. I mentioned that a positive interest in shamanism was growing in Europe and America. I described an email I had received from an Italian looking for a "real Koryak shaman" to invite to a conference, and my bewilderment at how to answer him. When I returned to Kamchatka in 2001, I learned that he had found Aunt Masha Yetneut, Valeri's mother, and she was going to Italy. I commented to Nina Milgichil that I was unsure what a 'real shaman' was or if Aunt Masha were one, but if these people in Italy thought she were a real shaman, that was fine. She certainly knows a lot about Koryak cosmology and ritual. Nina Nikolaevna frowned and disagreed with my use of the term 'shaman': 
It is not shamanism. It is true Koryak art (Eto istinnoe koriakskoe iskusstvo). Nervous people go into ecstasy. When I am dancing sometimes I lose myself too, don't notice anything else. Rituals require a leader, someone leading them - the oldest, wisest - the younger ones watch and learn, knowing that they will lead [in the future]. Maria Tepenovna [Yetneut] learned and now she leads. There are some people who know healing herbs, but they're not shamans.

The conversation quickly segued into ethnic dance groups, underscoring the sacred power implicit in Koryak dances and their performances:

Mengo isn't a real (nastoyashi) cultural dance. It's stylised. Weyem is better. I also argued with them, and the last time they performed here they were good, had good stuff, the right moves. One needs to dance, sing, play from your soul. Each person follows his own lead. Fakel has that, not all in lock-step like a bunch of robots. When you play a drum, a good drum takes pains and care to make and to maintain. It is a musical instrument. When they hear a really good drum, they think it's shamanism. It's really Koryak art or music. You become one with the drum. It should be an extension of you, of your soul.

I am quite sure that Milgichil has not studied Durkheimian sociology, but her passionate views on dance, ritual, and the healing role of the dance ensemble (and the public rituals constituting their performances) recalled Marcel Mauss's conclusion to The Gift (1990) to my mind. Nina Milgichil is working to foster a moral community through Koryak ethnic dance. Her husband Vasili was officially director of the group, but Nina remained the spiritual leader. While I was in Manily in 2001, she organised a Fakel performance in her front garden for my wife and me, as we videotaped and photographed the ensemble. Originally she just wanted a few people, since the space was cramped, but word went round the village in just a few hours, and nearly everyone turned up to perform for the Americans. Nina Milgichil was pleasantly surprised that some of the teenage girls who had joined the Protestant sect also came and danced, and talked to me about sewing their parkas and their involvement with Koryak traditions.

Nina Milgichil's choreography departs from other ensembles by eschewing a total coherence of collective stage presentation. Dancers are not necessarily in sync with one another; a large group of a dozen or more performers crowd a small stage and dance in small groups of two, three or four people. Individuals are encouraged to pursue their own style and develop unique moves while remaining iconic of elders' dances. Milgichil's elder son, for example, is famous 
in the village for a particularly beautiful style; he seems to float across the stage or ground. Thus, Fakel performs genuine Koryak dances in Sapir's sense because it does not force individuals to slavishly follow a stagnant vision of tradition, but encourages individuals to fulfil their maximum potential through harmonious pursuit of a living tradition. Milgichil encourages other youth in the group to talk to their own grandparents, and these relationships are indexed in the other dancers' performances. While Gil and Yetneut usually choreographed a dance down to the smallest move and gesture, Milgichil takes a more improvisational approach, forcing each performer to bring her or his own self to the performance in a new way every time. Thus, she inculcates a sense of agency and self-worth in young people through dance performances.

I discuss Nina Nikolaevna Milgichil's work with young people in detail because it is not exceptional. Milgichil is exceptional in her eloquence and explicit ideology of moral renewal through cultural revival, but certainly not alone. I was invited to two Ololo hunting rituals in Tymlat in 1997 by the charitable group Aboriginal Woman, which had partially financed these two and other Ololo rituals in a different village. At the rituals in Tymlat I met a primary school teacher from Khairiuzovo who had come for her own folkloric research - to document the living ritual and sacred practices in order to invigorate the moral life of children and adults in her own village that had long ago abandoned traditional Koryak rituals. There are many more examples of such young grandmothers and grandfathers taking responsibility for the moral life of young people. Most importantly, they and others were nearly unanimous in the opinion that young people responded positively to such initiatives.

\section{CONCLUSION}

Tradition and innovation are connected to relationships between youth and elders. The authenticity of forms is an index of these relationships. Youth who perform 'proper' Koryak (or Even or Chukchi, etc.) dances are those who have solid social relationships with particular elders. They have both technical skills (many besides dancing) and a reputation for a solid moral grounding in the traditions of the ancestors. The youth who stand out as exceptionally skilled, however, are those who bring in new shapes to these old forms. Thus, the positive valuation of dances as "good" or "traditional" or "correct" is a simultaneous positive valuation of the dancers as persons. Traditional dances in Kamchatka are more than mimesis; they are not really copies of anything, just as a jazz solo is not a copy, even if it contains iconic elements of the song's melodic line and stays within the song's harmonic structure. Since elders are the em- 
bodiment of tradition, these traditions will inevitably change as current elders pass on to the ancestors and are replaced by younger generations. The only cultures that do not change are dead ones.

Dancing in Kamchatka concerns more than cultural continuity or self-fulfilment. David Koester (2005: 651) points out that dance troupes are connected to cultural revival movements or ethnic politics in the minds of many Kamchatkans. The Soviet authorities supported ethnic dance ensembles as a genre of 'safe' cultural expression which would be 'national in form, Socialist in content'. I have tried to suggest here that the content of ethnic dance ensembles and performances easily accommodates other political agendas, as well. While I have discussed only three dance ensembles, there are scores of dance ensembles up and down the peninsula dedicated to performing indigenous cultural dances. These groups often travel locally, and many are invited to international events, usually as representatives of native Kamchatka or Siberia. Dancers in Mengo are professionals, and although their living is meagre by any material standard, it remains viable. The disingenuity inherent in Mengo performers' claims that they are not trying to represent authentic traditions lies in the fact that much of their national and international touring is based precisely upon their identity as a 'Koryak' ensemble, or at least one that performs native Kamchatkan dances.

The semiotics of Kamchatkan dances is such that the identity of the performer is irrelevant. While Western audiences may expect/prefer/demand that performers of Koryak dances have some authentic claim to a Koryak identity, Kamchatkans place more importance on the authenticity of the knowledge generating the performance. Koryak traditions may come from Koryak elders, but traditions (and Koryak culture generally) may be learned and "carried" by anyone. We may find that, as Koryak culture (e.g., dances, souvenirs, shamanic knowledge) becomes an increasingly valuable commodity, people identifying themselves as Koryak and other indigenous Kamchatkans may shift to a more exclusive, essentialising discourse of culture in order to prevent the Russians and Ukrainians who have already appropriated their land and material assets from appropriating their spiritual and cultural assets as well (cf. Harrison 1999, 2000). 


\section{ACKNOWLEDGEMENTS}

This paper came out of the conference in Tartu, organised by Aimar Ventsel in October, 2004. Subsequent versions of this paper were presented at the University of Manchester on 21 February 2005 and at the College of Wooster (Ohio) on 17 November 2005, and I benefited considerably from the discussion there. It initially appeared as Max Planck Institute for Social Anthropology Working Paper No. 79. I want to thank Otto Joachim Habeck, Rozita Dimova, and Deema Kaneff for insightful comments. Research Funding was provided by the Academic for Educational Development NSEP Program, a Wenner-Gren Foundation Dissertation Improvement Grant, an IARO Eurasia Fellowship from the International Research \& Exchange Board (IREX), the National Endowment for the Humanities, USA, and a Summer Scholars Fellowship, California State University, Chico.

\section{NOTES}

${ }^{1}$ Upper Paren is a small village of reindeer-herding Koryaks in Magadan Oblast. The Koryak Okrug village of Paren (or 'Ust-Paren') downriver is mostly inhabited by Nymylan Koryaks, but both places are closely linked through kinships and friendships. Most of my data comes from villages in the Koryak Okrug.

${ }^{2}$ Variously translated as 'region' and 'district', okrug is an administrative territory associated with a small ethnic minority. Okrugs were first created in 1930 as 'national districts', then changed to 'autonomous' in the 1970s. Recently, the Koryak Autonomous Okrug and Kamchatka Oblast approved a referendum to unite into a single Kamchatka Krai as part of a Kremlin initiative to fold all 10 okrugs back into the neighboring territories of which they were a part until 1993.

3 Mengo established itself as a separate administrative entity in 1998 in order to pursue opportunities for commercial and non-commercial ventures not available to government institutions. In 2001, Mengo moved to the town of Vilyuchinsk (across the bay from Petropavlovsk-Kamchatski), where they took up residence at the palace (dvorets) of culture (a larger and better equipped version of a house of culture).

${ }^{4}$ I use the term 'modern dance' only in contradistinction to classical ballet, for which Soviet and Russian groups are famous, and indigenous dance forms adapted to the stage. I do not mean to imply a specific dance genre, called 'modern dance' by choreographers and other specialists.

${ }^{5}$ For a critique of nationalist models of culture and of social science that inadvertently falls into nationalistic traps, see Handler (1988). Boas (1911) and Sapir (1921: $207-220$; 1933) cogently argued long ago that the categories of race, language and culture do not overlap. Barth (1969) makes a similar argument again, showing how such models are embedded in particular social and political orders. 
${ }^{6}$ For a nuanced analysis of boundaries and borders in a Boasian theory of culture, see Bashkow (2004) and Bunzl (2004).

7 Goldenweiser emphasises the point himself in a subsequent passage (1917: 449).

8 Typologies are, of course, vital to good anthropology, especially where one is interested in morphology (in biology, material studies, or linguistics), but typologies are themselves not explanations (Boas 1974).

9 Thus I believe that Kasten (2004) is a misreading of my chapter in that same volume (King 2004).

${ }^{10}$ During a seminar at the University of Manchester, Department of Social Anthropology, where I presented a previous version of this paper, discussion called into question the appropriateness of the English term 'authenticity' for analysing the value of culturally loaded performances like dances. While I am not ready to repudiate claims made in King (2004) and Kaneff and King (2004), I think that a more general discussion of value and meaning of ethnic dances in Kamchatka can proceed better without the term 'authenticity'.

${ }^{11}$ Zhornitskaia (1983) summarises the history of some of the more important dance groups in Kamchatka, including Mengo. Kravchenko (1995) provides a celebratory history of Mengo and some of the other ensembles founded by Mengo dancers.

${ }^{12}$ Police concluded that Yetneut's death was suicide after a short investigation.

${ }^{13}$ Yekaterina Gil and Tatiana Romanova (Niuman's wife) are Even and Itelmen, respectively, and have played a significant role as dancers and artistic leaders in the Kamchatkan dance scene. I do not discuss them in detail because I have little data on their activities, and my interviews with them were limited to several short conversations.

${ }^{14}$ Descriptions of dances, including photographs and video clips, can be found at http:/ /www.koryaks.net/.

${ }^{15}$ Fishing camps, reindeer herds, and similar spaces "in the tundra" or "on the shore" are understood as protoypically indigenous spaces, the loci of indigenous culture, by all people living in Kamchatka (King 2002a, 2002b).

${ }^{16}$ I realise that 'indigenous' is a problematic category in anthropology, and it is no less problematic in Kamchatka. However, intense settler colonisation in northern Kamchatka is barely a generation old, and people in Kamchatka readily make a distinction between locals/natives (mestnye) versus newcomers (priezzhie). Native identity in practice is self-ascribed and mostly a function of primary social loyalties and, to some degree, lifestyle where genealogical identities are complex (i.e., mixed).

${ }^{17}$ See Koester (2002) for a discussion of the seriousness of such "recreational" activities as song and dance. 


\section{REFERENCES}

Barth, Fredrik 1969. Introduction. In: F. Barth (ed.) Ethnic Groups and Boundaries: The Social Organization of Culture Difference. Bergen: Universitetsforlaget, pp. 9-38.

Bashkow, Ira 2004. A Neo-Boasian Conception of Cultural Boundaries. American Anthropologist. Vol. 106, No. 3, pp. 443-458.

Benjamin, Walter 1968. The Work of Art in the Age of Mechanical Reproduction. In: H. Arendt (ed.) Illuminations: Essays and Reflections. New York: Schocken Books, pp. 217-252.

Boas, Franz 1911. Introduction. Handbook of American Indian Languages. Vol. 1. Bureau of American Ethnology Bulletin 40. Washington, D.C.: United States Government Printing Office, pp. 1-76.

Boas, Franz 1974. The Principles of Ethnological Classification. In: G. Stocking (ed.) A Franz Boas Reader: The Shaping of American Anthropology, 1883-1911. Chicago: University of Chicago Press, pp. 61-71.

Bunzl, Matti 2004. Boas, Foucault, and the "Native Anthropologist": Notes Toward a Neo-Boasian Anthropology. American Anthropologist. Vol. 106, No. 3, pp. 435442.

Goldenweiser, Alexander A. 1917. The Autonomy of the Social. American Anthropologist. Vol. 19, No. 3, pp. 447-449.

Grant, Bruce 1995. In the Soviet House of Culture: A Century of Perestroikas. Princeton: Princeton University Press.

Handler, Richard 1988. Nationalism and the Politics of Culture in Quebec. Madison: University of Wisconsin Press.

Harrison, Simon 1999. Identity as a Scarce Resource. Social Anthropology. Vol. 7, pp. 239-251.

Harrison, Simon 2000. From Prestige Goods to Legacies: Property and the Objectification of Culture in Melanesia. Comparative Studies in Society and History. Vol. 42, pp. 662-679.

Jochelson, Waldemar 1908. The Koryak. In: F. Boas (ed.) American Museum of Natural History Memoirs. Vol. 10, Parts I and II. The Jesup North Pacific Expedition. Leiden: E. J. Brill.

Jochelson, Waldemar [Iokhel'son, V. I.] 1997. Koriaki: Material'naia kul'tura i sotsial'naia organizatsiia [Koryaks: Material culture and social organization]. Ch. M. Taksami (ed.) St Petersburg: Nauka.

Kaneff, Deema \& King, Alexander D. 2004. Owning Culture. Focaal: European Journal of Anthropology. Vol. 44, pp. 3-19.

Kasten, Erich 2004. Ways of Owning and Sharing Cultural Property. In: E. Kasten (ed.) Properties of Culture - Culture as Property: Pathways to Reform in Post-Soviet Siberia. Berlin: Dietrich Reimer Verlag, pp. 9-32.

King, Alexander D. 2002a. Reindeer Herders' Culturescapes in the Koryak Autonomous Okrug. In: E. Kasten (ed.) People and Land: Pathways to Reform in PostSoviet Siberia. Berlin: Dietrich Reimer Verlag, pp. 63-80. 
King, Alexander D. 2002b. "Without Deer There is No Culture, Nothing”. Anthropology and Humanism. Vol. 27, No. 2, pp. 133-164.

King, Alexander D. 2004. Authenticity and Real Cultural Properties in the Russian Far East. In: E. Kasten (ed.) Properties of Culture - Culture as Property: Pathways to Reform in Post-Soviet Siberia. Berlin: Dietrich Reimer Verlag, pp. 51-65.

Koester, David 2002. When the Fat Raven Sings: Mimesis and Environmental Alterity in Kamchatka's Environmentalist Age. In: E. Kasten (ed.) People and Land: Pathways to Reform in Post-Soviet Siberia. Berlin: Dietrich Reimer Verlag, pp. 45-62.

Koester, David 2005. Global Movements and Local Historical Events: Itelmens of Kamchatka Appeal to the United Nations. American Ethnologist. Vol. 32, No. 4, pp. 642-659.

Kravchenko, Valeri 1995. Mengo. Petropavlovsk-Kamchatski: RIO KOT.

Kroeber, Alfred 1917. The Superorganic. American Anthropologist. Vol. 19, No. 2, pp. $163-213$.

Krushanov, Andrei I. (ed.). 1993. Istoriia i kul'tura koriakov [The history and culture of Koryaks]. St Petersburg: Nauka.

Mauss, Marcel 1990. The Gift: The Form and Reason for Exchange in Archaic Societies. W. D. Halls (transl.). New York: W. W. Norton.

Peirce, Charles S. 1998. The Essential Peirce: Selected Philosophical Writings. Bloomington: Indiana University Press.

Pika, Aleksandr (ed.) 1999. Neotraditionalism in the Russian North:Indigenous Peoples and the Legacy of Perestroika. Seattle: University of Washington Press.

Sapir, Edward 1917. Do we need a superorganic? American Anthropologist. Vol. 19, No. 3, pp. 441-447.

Sapir, Edward 1921. Language: an introduction to the study of speech. New York: Harcourt Brace Javanovich.

Sapir, Edward 1933. "Language". Encyclopaedia of the Social Sciences. Vol. 9. New York: Macmillan, pp. 155-169.

Sapir, Edward 1949. Culture, genuine and spurious. In: D. G. Mandelbaum (ed.) Selected Writings in Language, Culture and Personality. Berkeley: University of California Press, pp. 308-332.

de Saussure, Ferdinand 1959. Course in General Linguistics. New York: Philosophical Library.

Silverstein, Michael 2004. "Cultural" Concepts and the Language - Culture Nexus. Current Anthropology. Vol. 45, No. 5, pp. 621-652.

Silverstein, Michael 2005. The Poetics of Politics: "Theirs" and "Ours". Journal of Anthropological Research. Vol. 61, No. 1, pp. 1-24.

Taussig, Michael T. 1993. Mimesis and Alterity: a Particular History of the Senses. New York: Routledge.

Zhornitskaia, Maria I. 1983. Narodnoe khoreograficheskoe iskusstvo korennogo naseleniia severa-vostoka Sibirii [Folk choreography of the indigenous populations of northeast Siberia]. Moscow: Nauka. 